Research article

\title{
An approach to the implementation of Low Impact Development measures towards an EcoCampus classification
}

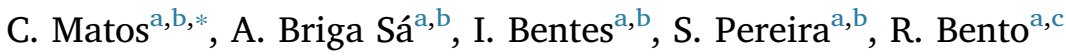 \\ ${ }^{a}$ ECT-School of Science and Technology, University of Trás-os-Montes e Alto Douro UTAD, Quinta de Prados, 5000-801 Vila Real, Portugal \\ ${ }^{\mathrm{b}}$ C-MADE- Centre of Materials and Building Technologies, University of Beira Interior, 6201-001 Covilhã, Portugal \\ ${ }^{\mathrm{c}}$ Centre for Transdisciplinary Development Studies, University of Trás-os-Montes e Alto Douro, Quinta de Prados, 5000-801 Vila Real, Portugal
}

\section{A R T I C L E I N F O}

\section{Keywords:}

LID

Peak discharge

EcoCampus

\begin{abstract}
A B S T R A C T
Impervious cover has important hydrologic impacts, namely the increased runoff volume and peak discharges in the rainwater network, which can lead to significant consequences like rapid urban floods with social, environmental and economic implications. LID (Low Impact Development) consist of distributed runoff management measures, like green roofs, pervious pavements, waterways covered with vegetation and filter trails, among others, that seek to control stormwater in the origin, reducing imperviousness. These solutions avoid increased runoff rate and volume, increase infiltration and groundwater recharge.

The main goal of the research work here presented is to study the hydrological impact of LID's in UTAD (University of Trás-os-Montes e Alto Douro) campus, which is an institution focused on sustainability, since it has defined in its Strategic Plan to achieve, in a near future, an EcoCampus classification. To achieve the proposed goal, the campus area was studied in detail in order to evaluate the technical possibility of LID's implementation. A peak discharge comparison was made between the current situation and the one with LID's implementation, using the rational method.

The results showed that peak discharges reduction between 68 and $95 \%$ may be achieved with LID solutions in UTAD campus.
\end{abstract}

\section{Introduction}

The progressive growth of urban areas has led to an extensive soil sealing mainly through the occupation by buildings, streets and sidewalks with important impacts in the environment quality and hydrology of the urban watersheds.

In fact, soil sealing prevents rain from being absorbed by the soil, promoting its filtration and thus removing some of its pollutants before recharging groundwater or increasing the superficial rivers flow. On the other hand, increased runoff volume anticipates the flood and increases peak discharges in the stormwater network, what may lead to significant consequences like rapid urban floods with social, environmental and economic implications.

Moreover, it should be noted that rainfall patterns have been changing due to climate changes. Extreme climatic events have been occurring, characterized by high frequency of high rainfall intensity. These occurrences cause the inadequate drainage of wastewater/ stormwater and, traditionally, drainage capacity improvement relies on very expensive and sometimes impracticable measures. Therefore, it is important to introduce measures to delay the occurrence of runoff peaks, to reduce their volume, as well as to improve the quality of water flowing into streams. The use of Low Impact Development (LID) plays an important role in this context being practices used to restore the natural hydrology of a site.

LID measures, among others, consist of distributed runoff management actions, like green roofs, pervious pavements, waterways covered with vegetation and filter trails, which seek to control stormwater in the origin, reducing imperviousness (Qin et al., 2013).

Green roofs are emerging building technologies that can help on the mitigation of the impacts caused by the impervious cover, namely by the stormwater runoff reduction (Karteris et al., 2016). This sustainable solution can be applied in industrial, administrative, commercial or residential buildings. According to FLL Guideline for Green Roofs (2008), green roofs are divided into intensive and extensive types, depending on the use, the construction factors, the type of plants used and the required maintenance degree. Kosareo and Ries (2007) refer to

\footnotetext{
* Corresponding author. Universidade de Trás-os-Montes e Alto Douro (UTAD), Escola de Ciências e Tecnologia, 5000-801 Vila Real, Portugal. . E-mail address: crismato@utad.pt (C. Matos).

URL: http://www.utad.pt (C. Matos).
} 
green roofs as a passive technique which can be used at the urban context in order to respond to environmental issues. The hydrological performance of a green roof was reported in several studies. Some of the conclusions refer that this LID technique can reduce $60-70 \%$ of a stormwater volume compared to a conventional roof (Dietz, 2007) and that green roofs may reduce the peak discharge by $30-78 \%$ compared to a standard roof (Alfredo et al., 2010). A review on this field presented by Castleton et al. (2010) refer that this type of system offers buildings and their surrounding some benefits, namely the runoff water quality improvement (Berndtsson, 2010), rainwater management (Mentens et al., 2006; Stovin et al., 2012) and the coverage useful life extension (Teemusk and Mander, 2009).

Pervious pavements are a solution used to reduce the hydrologic impacts of urbanization through considerable reductions in peak discharges and runoff volumes through storage of runoff within an aggregate base layer and infiltration into the original soil (Fassman and Blackbourn, 2010). This study reported that this type of LID delays and mitigates the peak flow. Indeed, the peak flow from a pervious pavement under drain is slower and tends to show less variation than the one from asphalt surface (Fassman and Blackbourn, 2010). In 2003, Abbot and Comino-Mateos evaluate the effect of a pervious pavement on the outflow from a car park and concluded that on average, $77.5 \%$ of the runoff remained on the system during a storm. Several tactics of pervious pavements may be employed in order to increase surface permeability, such as (Dover, 2015): gravel: not adequate to stand loads; pervious asphalt: very alike to tarmac, the only difference is its capacity to infiltrate water; porous concrete: no fine aggregates are used so gaps between stones linked by cement provide drainage; pervious blocks: rain may be drained by pores in the surface; wheel tracks: the driving area is a hard surface and the rest is green; open concrete blocks or plastic blocks: the surface that bear load is covered with open blocking where gravel or a similar material is inserted in order to support plant growing, like grass.

According to Arezes (2015), waterways covered with vegetation, also called infiltration ditches, are control devices, in the origin, with longitudinal development and generally of small depth. This system allows to concentrate the flow from adjacent areas and create conditions for infiltration along its length. Its volume should be enough to avoid flooding in case of severe precipitation. It can also act as a rainwater retention and treatment device (Canholi, 2014). This solution can be applied at roadsides and can also be well integrated in the urban environment, specifically in green spaces.

Filter trails are bands of permanent vegetation, applied on sloping ground, which are used to retain sediments or other materials, to reduce some of the rainfall flow through the vegetation. Its efficiency depends on the density and time of contact with vegetation (Swartz and Belan, 2010). These bands are a suitable solution for treating rainwater from relatively small areas such as roads.

The use of this type of techniques allows urbanized areas to be more hydrologically and environmentally efficient and so its implementation should be considered in an EcoCampus achievement. EcoCampus is an Environmental Management System (EMS) and an award scheme for the higher education sector which allows universities to be recognised for addressing key issues of environmental sustainability, including carbon reduction (EAUC, 2018). It works as a gradual classification scheme that splits the international standards for EMSs (ISO 14 001) in four bite sized pieces and the highest award (Platinum) is the equivalent of ISO 14001 international standard (Shiel and Smith, 2017). In this context, one of the objectives of UTAD is the recognition of the University Campus as an EcoCampus. It includes the ISO 14001 standard certification and, in addition, the ISO 50001 standard classification, seeking to intervene, both in the energy consumption reduction and in the water and waste management, since from the perspective of sustainability, the environment and energy are interconnected.

The present research aims to study the hydrological impact of LID's in the University of Trás-os-Montes e Alto Douro (UTAD) campus. To

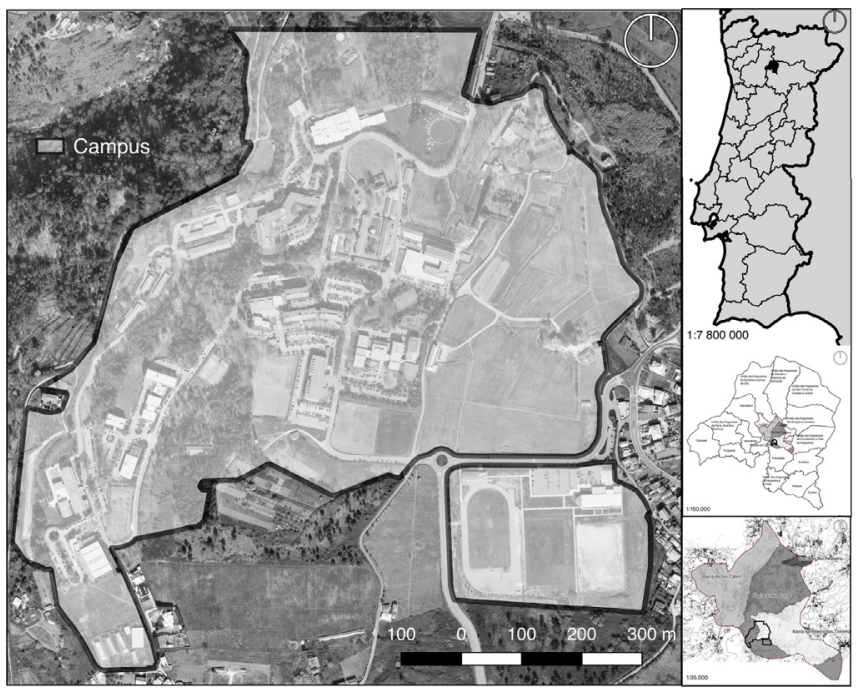

Fig. 1. Study area location.

achieve the proposed goal, the campus area was studied in detail in order to evaluate the technical possibility of LID's implementation in what concerns to peak discharge reduction. A comparison between the real situation and the one with LID's implementation was made.

\section{Material and methods}

\subsection{Case study description}

UTAD campus is located in the Southern part of the city of Vila Real. The study area of the campus has 66.69 ha and includes part of the wooded area that was kept intact, providing university users a warm and quiet environment. In addition to the wooded areas, there are green areas, with about 30 ha of land, used for agriculture and to provide support to Agricultural Sciences Departments. UTAD campus includes a botanical garden with about 1000 living species (Fig. 1).

According to the Vila Real water and waste management entity (EMARVR - Água e Resíduos de Vila Real E.M., S.A.), the urban area of the city has 1706 ha and contributes to four hydrographic basins: Ribeira das Toirinhas (418.77 ha), Rio Cabril (590.51 ha), Rio Corgo ( 660.89 ha) and Rio Pequeno ( 36.23 ha). The study area drains to two of these basins, which are Ribeira das Toirinhas basin (31.96 ha, representing $7.6 \%$ of the urban area of this basin) and Corgo River basin ( 34.73 ha, representing $5.3 \%$ of the urban area of this basin). This characterization is important to understand the impact of LID's measures at UTAD campus in the hydrographic basin.

In what concerns to the surface use, approximately $24 \%$ of the study area is covered with impervious surfaces, where $7.22 \%$ are buildings, $9.48 \%$ are roads, $4.76 \%$ are sidewalks and $2.82 \%$ are parking areas. All of these spaces may be converted in order to reduce the impervious area of the campus.

Rainwater in UTAD campus is drained in a storm sewer system separated from waste water network. However, there are critical points along the network where the two nets join and so they are discharged at the same point in the municipal discharger. After that, the wastewater is treated in the municipal wastewater treatment plant. The rainwater that circulates independently is discharged in a natural course of water.

\subsection{Data collection and analysis methods}

\subsubsection{Areas to convert}

Information regarding land cover was needed in order to correctly classify by cover material the different impervious areas of the Campus. Publicly available datasets regarding land cover like the Corine Land 
Cover (EEA, 2000), which uses a Minimum Mapping Unit (MMU) of 25 ha, or the Portuguese Land Cover and Land Use Dataset (COS), with a MMU of 1ha (Caetano et al., 2010), do not have the required spatial resolution. Also height information was needed in order to classify the different impervious areas into slope thresholds. This information was important to determine the different corresponding runoff coefficients and the available digital cartography with 1:10.000 resolution doesn't have the necessary resolution to produce the required Digital Terrain Model (DTM), so high resolution imaging obtained through photogrammetry technology with Pix4Dmapper ${ }^{\mathrm{TM}}$ software applied to the high resolution UAV images was used. Buildings, roads, sidewalks and parking lots were digitized and classified by its cover material from an orthophotomosaic with $11 \mathrm{~cm}$ per pixel resolution. A DTM with $56 \mathrm{~cm}$ per pixel resolution was also produced in order to extract a slope raster surface in order to classify roads and sidewalks by slope percentage. The slope raster surface was reclassified with the defined slope percentages thresholds $(0-1.5,1.5-8$ and $>8)$ to which a majority filter with a convolution window of 10 pixels was applied in order to remove small incongruent slope clusters and obtain a smoother slope surface.

\subsubsection{Peak discharge calculation: the rational method}

For hydraulic designs on very small basins, a complete hydrograph of runoff is not mandatory. The peak discharge of the hydrograph is usually enough (David, 2006). The rational method is a simple way for estimating a design discharge from a small watershed. It was developed by Kuichling (1889) for small drainage basins in urban areas. The rational method is the basis to design many small structures (David, 2006).

The application of the rational method is based on a simple equation that relates the runoff coefficient, the maximum average intensity of rainfall for a particular time (tc), and the drainage area with the peak flow:

$Q=C . I . A$

where:

$$
\begin{aligned}
& Q=\text { Peak Flow }\left(\mathrm{m}^{3} / \mathrm{s}\right) \\
& C=\text { runoff coefficient (dimensionless) } \\
& I=\text { maximum average intensity }(\mathrm{m} / \mathrm{s}) \\
& A=\text { drainage area }\left(\mathrm{m}^{2}\right) .
\end{aligned}
$$

In the present study, the rational method was applied to compare the peak discharge of the current situation with the one obtained for several scenarios considering the LID's measures implementation.

\subsubsection{Runoff coefficients}

The runoff coefficient, $C$, is a non-dimensional coefficient that considers the integrated effects of rainfall interception, infiltration, depression storage and temporary storage in transit on the peak rate of runoff (ASCE, 1992). It is generally presented as the ratio between the total depths of runoff and the total depth of precipitation:

$C=R / L$

where, $R$ is the total depth of runoff and $L$ is the total depth of precipitation. Indeed, the runoff coefficient represents the fraction of rainfall converted to runoff. Decades of practical experience with the rational formula have led to some accepted ranges of values for this coefficient. Some of them are presented in Table 1.

\subsubsection{Rainfall intensity}

Rainfall intensity $(I)$ is a function of geographic location and return period. It represents the maximum average rainfall intensity over a duration of precipitation equal to the time of concentration for the considered area. This combination of average intensity and duration must have a return period equal to the desired return period of the peak discharge. The relation between rainfall duration, rainwater intensity
Table 1

Runoff coefficients.

\begin{tabular}{ll}
\hline Material & Runoff Coefficient (ci) \\
\hline Ceramic tiles & $0,80-0,90$ \\
Zinc standing seam & $0,70-0,90$ \\
Metal panel roof system & $0,70-0,90$ \\
Green roof & 0,27 \\
Fiber cement roofing & $0,80-0,90$ \\
Concrete slab & $0,70-0,90$ \\
Asphalt concrete & $0,80-0,95$ \\
Segmented concrete blocks & $0,50-0,70$ \\
Granite cubes & $0,50-0,70$ \\
Limestone cubes & $0,50-0,70$ \\
Broken stone rustic pavement & $0,30-0,70$ \\
Concrete pavement & $0,70-0,90$ \\
Gravel & $0,35-0,75$ \\
Porous asphalt & $0,25-0,35$ \\
Wheel tracks & $0.02-0.05$ \\
Open concrete blocks or plastic blocks & $0.15-0.6$ \\
\hline
\end{tabular}

and rainwater return period is represented by a family of curves called the intensity-duration-frequency curves, or IDF curves. The IDF curves can be determined analysing rainwater events for a particular site or using standard meteorological diagrams. The Portuguese legislation (DL 23/98 of 23rd August) suggests the use of a formula to approach the intensity-duration-frequency curve. The formula is:

$I=a t^{b}$

where,

$t$ - Duration of precipitation (min).

$a, b$-regional parameters (non-dimensional) (Table 2).

The time of concentration, $t c$, is often defined as the time required for a parcel of runoff to travel from the most cinematically distant part of a basin to the outlet. It represents the time at which all the areas of the hydrographic basin are contributing to the runoff.

If the chosen rain duration is lower than $t c$, then the basin is not fully contributing to the runoff and the maximum value will not be achieved. If rain time is superior than $t c$, then the rainfall intensity will be lower than that at $t c$. Therefore, the estimated peak discharge will be lower than the maximum value. Thus, it is approached that the rain time is equal to $t c$.

Usually, in most engineering problems in Portugal, according to the Portuguese legislation (DL 23/98 of 23rd August) it is set that $t c$ depends on the surface slope (i), as presented in Table 3:

\section{Results and discussion}

\subsection{Data collection and analysis}

\subsubsection{Areas to convert}

A detailed description of the surface areas considered as possible to be converted was developed based in the methodology referred previously. Those areas were defined taking into account the type of use, cover, material and slope range (Table 6 and Figs. 2-5).

Table 2

IDF parameters for Vila Real.

\begin{tabular}{llllll}
\hline \multicolumn{5}{c}{ Return Interval (Years) } \\
\hline Parameter & 5 & 10 & 20 & 50 & 100 \\
A & 207.41 & 232.21 & 254.19 & 279.63 & 292.50 \\
B & -0.562 & -0.549 & -0.538 & -0.524 & -0.508 \\
\hline
\end{tabular}


Table 3

tc variation with the surface slope (i).

\begin{tabular}{ll}
\hline $\mathrm{i}$ & tc $(\mathrm{min})$ \\
\hline$\leq 1.5 \%$ & 15 \\
$1.5 \mathrm{~A} 8 \%$ & 10 \\
$>8 \%$ & 5
\end{tabular}

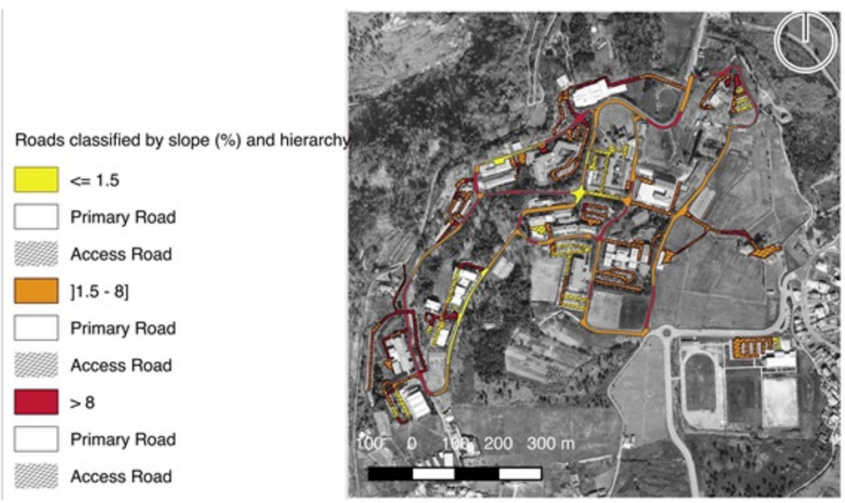

Fig. 2. Roads with possible conversion classified by slope and hierarchy.

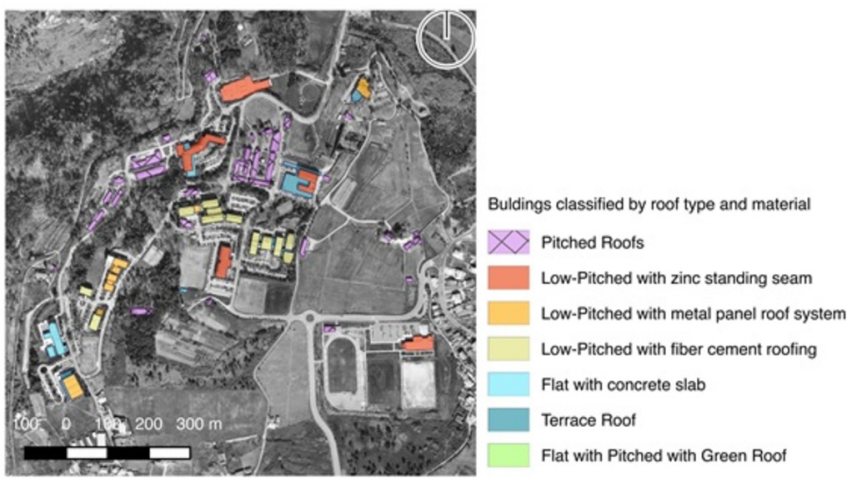

Fig. 3. Buildings with possible coverage conversion classified by roof type and material.

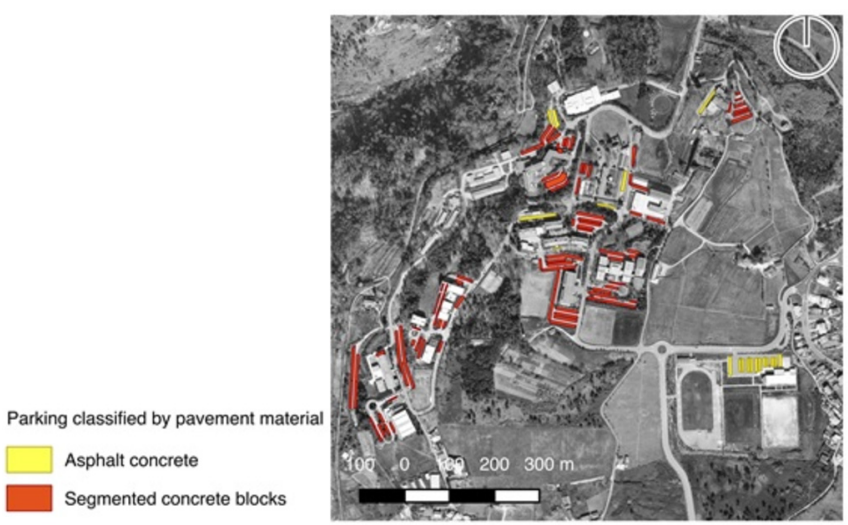

Fig. 4. Parking with possible conversion classified by pavement material.

\subsection{Peak discharge calculation}

\subsubsection{Current situation}

The runoff coefficients considered in this study were the ones presented in Table 1, according to the existing cover material in each area. The return periods to be used should be minor in cases of very flat basins with a high percentage of pervious spaces and be increased to

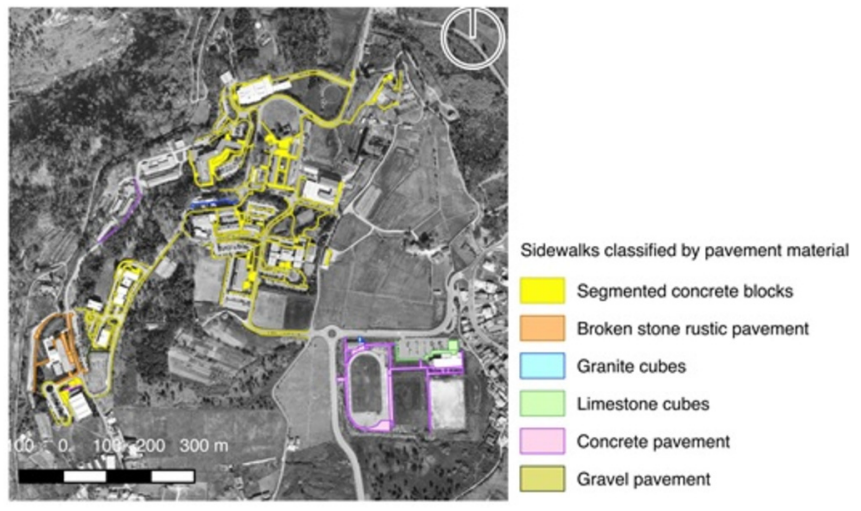

Fig. 5. Sidewalks with possible conversion classified by pavement material.

Table 4

Parameters $a$ and $b$ for rain intensity calculation.

\begin{tabular}{ll}
\hline TR & 15 \\
\hline $\mathbf{a}$ & 243,2 \\
$\mathbf{b}$ & $-0,544$ \\
\hline
\end{tabular}

Table 5

Rain intensity results.

\begin{tabular}{llll}
\hline & tc (min) & I (mm/h) & I (l/s) \\
\hline $\mathbf{1 . 5 \%}$ & 15 & 55,7404 & 0,015483444 \\
$\mathbf{1 . 5} \mathbf{A ~ 8 \%}$ & 10 & 69,4966 & 0,019304611 \\
$>\mathbf{8} \%$ & 5 & 101,327 & 0,028146389 \\
\hline
\end{tabular}

large, densely built and sloping basins, generally ranging from 5 to 25 years. The return period $(R T)$ used was 15 years, which is the current value used in this type of design in Portugal, and so, the coefficients $a$ and $b$ used where the ones presented in Table 5. These values were obtained by the linearly interpolation of the parameters $a$ and $b$ illustrated in Table 3 for a return period of 15 years. With these values and considering the slope of each area, the rain intensity was then calculated (Table 6).

In Table 7, it is presented the peak discharge obtained in each study area for the current situation of UTAD campus, according to the characteristics of the surface area presented in Table 4.

\subsubsection{LID'S implementation}

LID's implementation proposed in this case study consisted in the replacement of all the buildings cover by green roofs, in the placement of open concrete blocks or plastic blocks in parking's, sidewalks and secondary roads and in the replacement of asphalt concrete by pervious asphalt in primary roads. Table 7 presents the results of peak calculation in the case of LID's implementation.

It is important to address that green roofs will not totally reduce the discharge. This measure is an "at source" control measure and so it will reduce and delay the discharge. In fact, research on the effectiveness of extensive green roofs to reduce stormwater runoff has shown that they intercept, retain and evapotranspire between $34 \%$ and $69 \%$ of precipitation with an average retention of $56 \%$ (Gregoire and Clausen, 2011). Jarrett et al. (2006) suggested that an extensive green roof would retain $45 \%-55 \%$ of the annual rainfall volume. In the review presented by Gregoire and Clausen (2011), it is stated that the range in retention is partly due to the time of the studied year, sampling methods, climate and the calculate retention method used. The amount of precipitation retained by a green roof is improved by the number of increasing antecedent dry days preceding precipitation, lower rainfall 
Table 6

Area measurements and characteristics (material and slope) and peak discharge results for the current situation.

\begin{tabular}{|c|c|c|c|c|c|c|c|c|c|c|}
\hline \multirow[t]{2}{*}{ Use } & \multirow[t]{2}{*}{ Cover } & \multirow[t]{2}{*}{ Type of material } & \multicolumn{3}{|c|}{ Area per slope class $\left(\mathrm{m}^{2}\right)$} & \multirow[t]{2}{*}{$\operatorname{AREA}\left(\mathrm{m}^{2}\right)$ (ai) } & \multicolumn{3}{|l|}{$\mathrm{Q}(\mathrm{l} / \mathrm{s})$} & \multirow[t]{2}{*}{ Total (l/s) } \\
\hline & & & $\leq 1.5 \%$ & $1.5-8 \%$ & $>8 \%$ & & $\leq 1.5 \%$ & $1.5-8 \%$ & $>8 \%$ & \\
\hline \multirow[t]{10}{*}{ Buildings } & Terrace Roof & Concrete slab & 4902,26 & - & - & 4902,26 & 64,52 & - & - & 64,52 \\
\hline & High Pitched Roofs & Zinc standing seam & - & - & 412,08 & 412,08 & - & - & 9,86 & 9,86 \\
\hline & & Metal panel roof system & - & 121,18 & 803,87 & 925,04 & - & 1,99 & 19,23 & 21,22 \\
\hline & & Fiber cement roofing & - & 548,94 & 6201,05 & 6749,99 & - & 9,01 & 148,36 & 157,36 \\
\hline & & Ceramic tiles & - & - & 4530,82 & 4530,82 & - & - & 108,40 & 108,40 \\
\hline & Flat/Low-Pitched Roofs & Zinc standing seam & 2646,91 & 3257,69 & 7100,39 & 13004,99 & 34,84 & 53,46 & 169,87 & 258,16 \\
\hline & & Metal panel roof system & 109,07 & 1751,08 & 3687,61 & 5547,76 & 1,44 & 28,73 & 88,22 & 118,39 \\
\hline & & Green roof & 30,41 & - & - & 30,41 & 0,13 & - & - & 0,13 \\
\hline & & Fiber cement roofing & - & 623,28 & 8405,62 & 9028,90 & - & 10,23 & 201,10 & 211,33 \\
\hline & & Concrete slab & 3025,06 & - & - & 3025,06 & 39,81 & - & - & 39,81 \\
\hline \multirow[t]{2}{*}{ Parking } & & Asphalt concrete & 496,44 & 2700,77 & - & 3197,21 & 6,15 & 41,71 & - & 47,86 \\
\hline & & Segmented concrete blocks & 5428,60 & 8137,94 & 2032,84 & 15599,38 & 50,43 & 94,26 & 34,33 & 179,02 \\
\hline \multirow[t]{2}{*}{ Roads } & Primary & Asphalt concrete & 3480,85 & 15403,83 & 9194,71 & 28079,39 & 43,12 & 237,89 & 207,04 & 488,05 \\
\hline & Secondary & Asphalt concrete & 6764,85 & 21541,39 & 6806,66 & 35112,89 & 83,79 & 332,68 & 153,27 & 569,74 \\
\hline \multirow[t]{6}{*}{ Sidewalks } & & Segmented concrete blocks & 6351,23 & 9588,77 & 5841,80 & 21781,80 & 59,00 & 111,06 & 98,66 & 268,72 \\
\hline & & Granite cubes & - & 295,76 & - & 295,76 & - & 3,43 & - & 3,43 \\
\hline & & Limestone cubes & 485,50 & 934,46 & - & 1419,96 & 4,51 & 10,82 & - & 15,33 \\
\hline & & Broken stone rustic pavement & 187,97 & 1033,80 & 1054,98 & 2276,75 & 1,75 & 11,97 & 17,82 & 31,54 \\
\hline & & Concrete pavement & 4344,28 & 1397,93 & 154,59 & 5896,80 & 57,17 & 22,94 & 3,70 & 83,81 \\
\hline & & Gravel & - & 12,07 & 87,61 & 99,68 & - & 0,13 & 1,36 & 1,48 \\
\hline Total & & & 38253,43 & 67348,89 & 56314,63 & 161916,93 & 446,66 & 970,31 & 1261,22 & 2678,16 \\
\hline
\end{tabular}

Table 7

Peak discharge results after LID's.

\begin{tabular}{|c|c|c|c|c|c|c|c|}
\hline \multirow[t]{2}{*}{ Use } & \multirow[t]{2}{*}{ Cover } & \multirow[t]{2}{*}{ LID } & \multirow[t]{2}{*}{ Runoff Coefficient (ci) } & \multicolumn{3}{|l|}{$\mathrm{Q}(\mathrm{l} / \mathrm{s})$} & \multirow[t]{2}{*}{ Total } \\
\hline & & & & $\leq 1.5 \%$ & $1.5-8 \%$ & $>8 \%$ & \\
\hline \multirow[t]{10}{*}{ Buildings } & Terrace Roof & Green roof & 0,27 & 20,49 & & & 20,49 \\
\hline & High Pitched Roofs & Green roof & 0,27 & - & & 3,13 & 3,13 \\
\hline & & & 0,27 & - & 0,63 & 6,11 & 6,74 \\
\hline & & & 0,27 & - & 2,86 & 47,13 & 49,99 \\
\hline & & & 0,27 & - & - & 34,43 & 34,43 \\
\hline & Flat/Low-Pitched Roofs & Green roof & 0,27 & 11,07 & 16,98 & 53,96 & 82,00 \\
\hline & & & 0,27 & 0,46 & 9,13 & 28,02 & 37,61 \\
\hline & & & 0,27 & 0,13 & - & - & 0,13 \\
\hline & & & 0,27 & - & 3,25 & 63,88 & 67,13 \\
\hline & & & 0,27 & 12,65 & - & - & 12,65 \\
\hline \multirow[t]{2}{*}{ Parking } & & Open concrete blocks or plastic blocks & 0,15 & 1,15 & 7,82 & - & 8,97 \\
\hline & & & 0,15 & 12,61 & 23,56 & 8,58 & 44,76 \\
\hline \multirow[t]{2}{*}{ Roads } & Primary & Permeable asphalt & 0,25 & 13,47 & 74,34 & 64,70 & 152,51 \\
\hline & Secondary (Access) & Open concrete blocks or plastic blocks & 0,02 & 15,00 & 8,32 & 3,83 & 27,15 \\
\hline \multirow[t]{7}{*}{ Sidewalks } & & Open concrete blocks or plastic blocks & 0,15 & 14,75 & 27,77 & 24,66 & 67,18 \\
\hline & & & 0,15 & - & 0,86 & - & 0,86 \\
\hline & & & 0,15 & 1,13 & 2,71 & - & 3,83 \\
\hline & & & 0,15 & 0,44 & 2,99 & 4,45 & 7,88 \\
\hline & & & 0,15 & 10,09 & 4,05 & 0,65 & 14,79 \\
\hline & & & 0,15 & - & 0,03 & 0,37 & 0,40 \\
\hline & & & Total & 113,43 & 185,30 & 343,91 & 642,64 \\
\hline
\end{tabular}

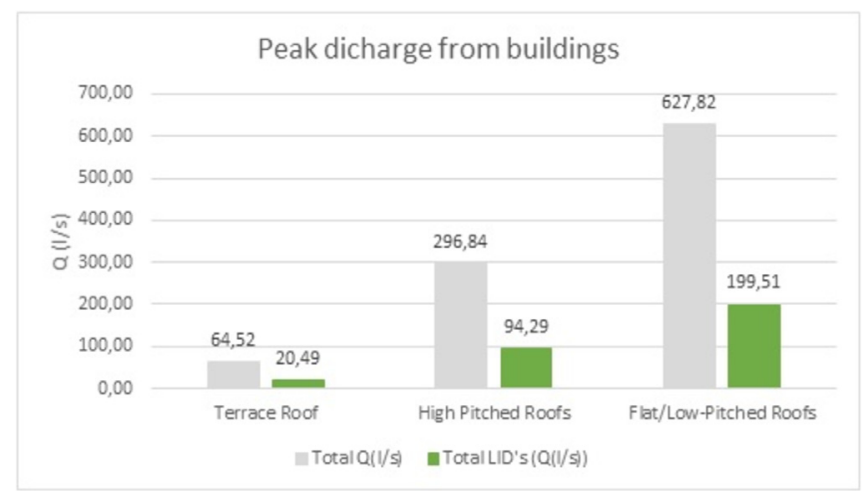

Fig. 6. Differences in peak discharges from building without and with LID's implementation.

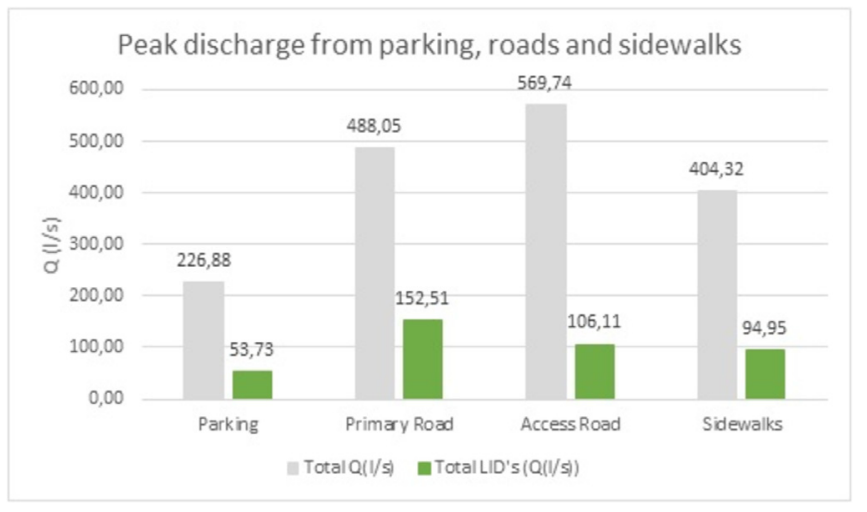

Fig. 7. Differences in peak discharges from parking, roads and sidewalks without and with LID's implementation. 


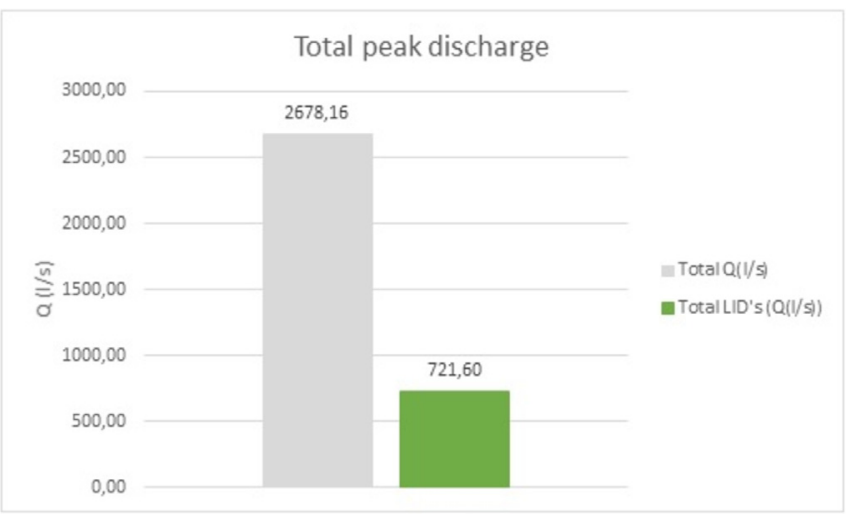

Fig. 8. Differences in total peak discharges without and with LID's implementation.

amount, higher temperature and evapotranspiration and a higher water holding capacity of the growing media. None of these factors were considered in the present study. However, given the already stated advantages of this passive and environmental solution, considering the possibility of implement it will certainly improve the main goal of an EcoCampus classification.

The obtained results showed that, with the implementation of green roofs in all the buildings of the campus, $68 \%$ of reduction/delay will be achieved. (Fig. 6). However, the most real scenario would be the conversion of the terrace and the Flat/Low pitched roofs in green roofs, what would represent $48 \%$ of peak discharge reduction/delay.

The conversion of the current parking's pavements in pervious pavements with open concrete blocks or plastic blocks would lead to $76 \%$ of peak discharge reduction (Fig. 7). Implementing the same solution for the secondary roads (access), the reduction would be of $95 \%$ (Fig. 7). Regarding the primary roads, using pervious asphalt, peak discharge would be reduced in 69\% (Fig. 7). In fact, according to bibliography, pervious pavements are well suited to substantial reduce peak discharge and runoff volume through storage of runoff within an aggregate base layer and infiltration into the underlying soil (Fassman and Blackbourn, 2010).

In a hypothetical scenario of implementing all the proposed measures, the reduction of the peak flow would be of 2035.5 l/s (Fig. 8) what represents $76 \%$ of peak discharge reduction.

As said, most of rainwater in UTAD campus is drained in a separated network and it is discharged in a natural water course near the campus. This practice will involve costs, such as: economic costs, once this stormwater is probably polluted, and so it has to be treated before discharge; environmental costs, if it is not treated.

The part of rainwater that circulates with the wastewater, by infiltration or by the junction in unitary networks, increases the costs to the institution, once it is paid to discharge in the municipal network, to be treated in the municipal wastewater treatment plant.

\section{Conclusions}

LID's practices are increasingly gaining interest from many developers and public policy makers seeking to find solutions for moving cities toward sustainability. The present study presented the effect on peak discharge of several LID's measures, in UTAD Campus, a university focused on sustainability and on the EcoCampus classification achievement. Peak discharges reductions between 68 and 95\% may be achieved using these techniques.

These values are a strong incentive to the use of LID's in urban areas, allowing to drastically delay and reduce peak flows. Taking into consideration climate changes, extreme events, such as heavy rainwater events that tend to become more frequent, it is easy to see that the use of these measures is becoming increasingly necessary and urgent.
The methodology used, although simple, has the advantage of being able to simulate, in an expeditious way, several scenarios to restore the permeability to urban areas in order to respond adequately to existing rainwater networks, mitigating the effect of floods in urban areas, which, generally have social, economic and environmental serious consequences.

These reductions should to be addressed in future researches already in progress.

\section{Acknowledgement}

This work was partially supported by the FCT (Portuguese Foundation for Science and Technology) through the project PEst-OE/ ECI/UI4082/2013 (C-MADE).

\section{References}

Alfredo, K., Montalto, F., Goldstein, A., 2010. Observed and modeled performance of prototype green roof test plots subjected to simulated low and high intensity precipitation in a laboratory experiment. J. Hydrol. Eng. 15, 444e457.

Arezes, L.D., 2015. Gestão Sustentável de Águas Pluviais em Ambiente Urbano. Guimarães: Universidade do Minho - Mestrado em Engenharia Civil. Master thesis in Civil Engineering.

ASCE, 1992. Design and Construction of Urban Stormwater Management Systems. Prepared by the Urban Water Resources Research Council of the American Society of Civil Engineers and the Water Environment Federation. ASCE Manuals and reports of Engineering Practice no77. WEF Manual of Practice FD-20, USA0-87262-855-8.

Berndtsson, J.C., 2010. Green roof performance towards management of runoff water quantity and quality: a review. Ecol. Eng. 36, 351e360.

Caetano, M., Nunes, A., Dinis, J., Pereira, M., Marrecas, P., Nunes, V., 2010. Memória Descritiva da Carta de Uso e Ocupação do Solo de Portugal Continental para 2007. Instituto Geográfico Portugês. http://www.igeo.pt/DadosAbertos/Docs/memoria_ descritiva_COS2007.pdf.

Canholi, Aluísio Pardo, 2014. Drenagem Urbana e Controle de Enchentes, 2. ${ }^{\text {a }}$ ed. Oficina de Textos, São Paulo.

Castleton, H.F., Stovin, V., Beck, S.B.M., Davison, J.B., 2010. Green roofs: building energy savings and the potential for retrofit. Energy Build. 42, 1582-1591.

David, T., 2006. The Rational Method. Civil Engineering Department, Texas Tech University, pp. 1-7.

Dietz, M.E., 2007. Low impact development practices: a review of current research and recommendations for future directions. Water, Air, Soil Pollut. 186, 351-363.

Dover, J.W., 2015. Green Infrastructure: Incorporing Plants and Enhancing Biodiversity in Buildings and Urban Environments. Routledge, Taylors and Francis Group, London and New York978-0-415-52123-9.

EAUC, 2018. EcoEcampus. Available at: http://www.eauc.org.uk/ecocampus Accessed October 15, 2018.

EEA, European Environment Agency, 2000. CORINE Land Cover. Corine Land Cover Technical Guide. http://www.eea.europa.eu/publications/tech40add.

Fassman, E.A., Blackbourn, S., 2010. Urban runoff mitigation by a permeable pavement system over impervious soils. J. Hydrol. Eng. 15, 475-485.

FLL, 2008. Guidelines for the Planning, Construction and Maintenance of Green-Roofing-Green Roofing Guideline. Research foundation for landscaping issues (Forschungsgesellschaft Landschaftsentwicklung Landschaftsbau), Bonn, Germany.

Gregoire, B.G., Clausen, J.C., 2011. Effect of a modular extensive green roof on storm water runoff and water quality. Ecol. Eng. 37, 963-969.

Jarrett, A., Hunt, W., Berghage, R., 2006. Annual and individual storm green roo stormwater response models. In: 2006 ASABE Annual International Meeting. Sponsored by ASABE, Oregon Convention Center, Portland, Oregon, 9-12 July.

Karteris, M., Theodoridou, I., Mallinis, G., Tsiros, E., Karteris, A., 2016. Towards a green sustainable strategy for Mediterranean cities: assessing the benefits of large-scale green roofs implementation in Thessaloniki, Northern Greece, using environmental modelling, GIS and very high spatial resolution remote sensing data. Renew. Sustain. Energy Rev. 58, 510-525.

Kosareo, Lisa, Ries, Robert, 2007. Comparative environmental life cycle assessment of green roofs. Build. Environ. 42, 2606-2613.

Kuichling, E., 1889. The relation between the rainfall and the discharge of sewers in populous districts. Trans. Am. Soc. Civ. Eng. 20, 1-56.

Mentens, J., Raes, D., Hermy, M., 2006. Green roofs as a tool for solving the rainwater runoff problem in the urbanized 21 st century? Landsc. Urban Plann. 77 (3), 217-226.

Qin, H., Li, Z., Fu, G., 2013. The effects of low impact development on urban flooding under different rainfall characteristics. J. Environ. Manag. 129, 577-585.

Shiel, C., Smith, N., 2017. An integrative approach to sustainable development within a university: a step-change to extend progress on multiple fronts BT - sustainable development research at universities in the United Kingdom: approaches, methods and projects. In: Leal Filho, W. (Ed.), Sustainable Development Research at Universities in the United Kingdom. Springer International Publishing, Cham, pp. 13-25. https:// doi.org/10.1007/978-3-319-47883-8_2.

Stovin, V., Vesuviano, G., Kasmin, H., 2012. The hydrological performance of a green roof test bed under UK climatic conditions. J. Hydrol. 414 (15), 148-161.

Swartz, K., Belan, G., 2010. Low Impact Development manual for the Lower maumee and Ottawa River Watersheds. American Rivers.

Teemusk, A., Mander, Ü., 2009. Green roof potential to reduce temperature fluctuations of a roof membrane: a case study from Estonia. Build. Environ. 44 (3), 643-650. 